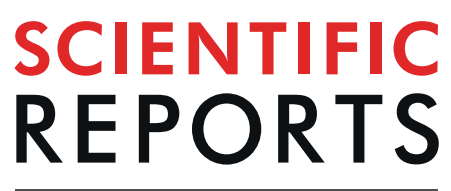

natureresearch

Check for updates

\title{
OPEN
}

Published online: 05 May 2020

\section{Publisher Correction: RNA-Seq transcriptome profiling in three liver regeneration models in rats: comparative analysis of partial hepatectomy, ALLPS, and PVL}

Dilek Colak (D, Olfat Al-Harazi, Osama M. Mustafa, Fanwei Meng, Abdullah M. Assiri $\mathbb{D}_{\text {, }}$ Dipok K. Dhar \& Dieter C. Broering

Correction to: Scientific Reports https://doi.org/10.1038/s41598-020-61826-1, published online 23 March 2020

In the original PDF version of this Article, Dilek Colak was omitted as jointly supervising this work.

This error has now been corrected in the PDF version of the paper; the HTML version was correct from the time of publication.

(1) Open Access This article is licensed under a Creative Commons Attribution 4.0 International (c) License, which permits use, sharing, adaptation, distribution and reproduction in any medium or format, as long as you give appropriate credit to the original author(s) and the source, provide a link to the Creative Commons license, and indicate if changes were made. The images or other third party material in this article are included in the article's Creative Commons license, unless indicated otherwise in a credit line to the material. If material is not included in the article's Creative Commons license and your intended use is not permitted by statutory regulation or exceeds the permitted use, you will need to obtain permission directly from the copyright holder. To view a copy of this license, visit http://creativecommons.org/licenses/by/4.0/.

(C) The Author(s) 2020 